\title{
New faunistic records of Pediciidae (Diptera, Insecta) from Europe
}

\author{
Levente-Péter Kolcsár, Edina TöröK \& Lujza KereszTeS
}

\begin{abstract}
Summary: Pediciidae, or hairy-eyed craneflies, are a small dipteran family within the super-family Tipuloidea. Most of species are associated with humid habitats and distributed mostly in mountainous areas. Here we report a number of species for the first time from various European countries. These are Dicranota (Ludicia) lucidipennis (EDwards, 1921) from Bosnia and Herzegovina, Dicranota (Paradicranota) brevicornis (Bergroth, 1891) from Montenegro, D. (P.) landrocki (CzizeK, 1931) and Ula (Ula) mollissima (Haliday, 1833) from Macedonia, Dicranota (Paradicranota) mikiana (LACKschewitz, 1940) and D. (P.) landrocki (CZIZEK, 1931) from Greece, D. (P.) minuta (LaCkschewitz, 1940) from Albania and P. (C.) straminea (Meigen, 1838) from Luxembourg.
\end{abstract}

Keywords: new faunistic records, hairy-eyed crane flies, Greece, Macedonia, Montenegro

\section{Introduction}

Pediciidae or hairy-eyed crane flies are distributed in all biogeographic regions, with the exception of the Afrotropic and Antarctic Regions (OOSTERBroeK 2017). The family comprises of 495 extant and 12 extinct species (Oosterbroek 2017, GaO et al. 2015), but it is suggested that new species and faunistic novelties can be expected from even wellrecorded areas such as Europe (UJvÁrosi and STARÝ 2003, Ujvárosi and BÁLINT 2012, DÉNES et al. 2016, PARAmonov 2009). Currently, 80 species belonging to five genera are known from the West-Palaearctic, though there have been frequent new faunistic records from the eastern regions (KereszTes et al. 2011, LANTSOv 2012, Mederos and EIroA 2015, ÖzGÜL and Koç 2016, HANCOCK et al. 2015, KolCSÁR et al. 2012, 2015, KolCSÁr and KereszTES 2016, KolCSÁR and TöröK 2017, Oosterbroek 2017, STARÝ 2014).

Here we report a number of species for the first time from various European countries.

\section{Material and methods}

Specimens were collected between 2003 and 2015 using sweep nets and material was stored in $96 \%$ ethanol or pinned and deposited in Diptera Collection of the Faculty of Biology and Geology, Babeş-Bolyai University, Cluj-Napoca, Romania (DCBBU) or in Hungarian Natural History Museum, Budapest (HNHM). The morphological characteristics of the male and female terminalia was examined after being macerated in $10 \% \mathrm{KOH}$. All collection data are available on the TransDiptera Online Database (KolCSÁr et al. 2018).

New faunistic records:

Order: DIPTERA

Family: PEDICIIDAE

Subfamily: PEDICIINAE 1921)

Dicranota (Ludicia) lucidipennis (EDWARDS, Material examined: Bosnia and Herzegovina, Obadi, Javor Mts., Srebrenica brook, $700 \mathrm{~m}, 44.1122^{\circ}$ $\mathrm{N} 19.3262^{\circ} \mathrm{E}, 04.07 .2010,1$ male, leg. W. GRAF (DCBBU); Nahorevo, Skakavac Mts., $1056 \mathrm{~m}$, $43.9490^{\circ} \mathrm{N} 18.4492^{\circ} \mathrm{E}, 12.07 .2008,6$ males, leg. W. GRAF (DCBBU).

Remarks: The species is widely distributed in Europe. Three colour form were reported, of which the dark coloured form is the most widespread (KoLCSÁR et al. 2014). In the Balkans a brown-coloured form was originally described as a separate species (Pedicia luteicolor) but later synonymized with $D$. lucidipennis (AlEXANDER 1975, STARÝ 2007). A third, yellowish form recently founded in the Carpathians (Kolcsír et al. 2014). The species is reported here for the first time from Bosnia and Herzegovina, where all specimens collected belonged to the brown-coloured (luteicolor) form.

Dicranota (Paradicranota) brevicornis (BERGROTH, 1891)

Material examined: Montenegro, Medjurecje, Maganik Mts., Mrtvica River, 320 m, $42.7336^{\circ} \mathrm{N}$ 
19.3335 ${ }^{\circ}$ E, 23.06.2017, 2 males, 3 females, leg. KolCsÁr L.-P., TÖRÖK E. (DCBBU).

Remarks: Faunistic records suggests that is a less common species, being mostly found in higher mountainous areas. Based upon the observations of the lead author (KoLCSÁR) the species is more frequently found at high elevations of up to $2200 \mathrm{~m}$ in Romania, where it seems to prefer cold streams with sandy or muddy banks. However specimens from Montenegro were collected at lower altitudes under sub-Mediterranean climatic conditions, around the very cold Mrtvica River (summer water temperature approximately $13-15^{\circ} \mathrm{C}$ ), which creates a cooler micro-climate in the area close to the river (Fig. 1A). The species flies during the summer to autumn period as is perhaps typical for many montane species.

\section{Dicranota (Paradicranota) mikiana (LACKSCHEWITZ, 1940) \\ Material examined: Greece, Ropodi country,} Sapka Mts, torrent in an oak forest, $651 \mathrm{~m}, 14 \mathrm{~km}$ East of Nea Sanda, $41.1271^{\circ}$ N 25.8871 ${ }^{\circ}$ E, 04.04.2007, 1 male, leg. MuránYi D. (HNHM).

Remarks: It is a rare species, which was reported only from Austria, Czech Republic, Romania and Slovakia (Oosterbroek 2018, Kolcsár et al. 2012). The species was recently collected in Serbia (GAVRYUSHIN in litt. 2015 see Oosterbroek 2018), and so our data suggests that the species is more widely distributed than previously thought, with these new observations from Greece. The available data suggests an early spring flight period.

\section{Dicranota (Paradicranota) minuta (LACKSCHEWITZ, 1940) \\ Material examined: Albania, Rrogam, spring} system of the River Valbona spring, $1457 \mathrm{~m}, 42.4103^{\circ}$ N 19.8228 ${ }^{\circ}$ E, 02.06.2005, 1 male, leg. MuránYI D. (HNHM).

Remarks: It is a rare montane species, known from the Alps, the Carpathians and the Caucasus. The biology and ecology of the species is largely unknown. In both Romania and Albania (Dinaric Alps) the species was collected around mountain spring habitat (Fig. 1B). Here we report for the first time from the Albania.

\section{Dicranota (Paradicranota) landrocki (CZIZEK,} 1931)

Fig. 2-3. Photos were taken from a specimen collected in Gârbău Valley, Cluj-Napoca, Romania, 15.04.2017.

Material examined: Republic of Macedonia, Maloviste, Pelister Mts., Pelister National Park, 1200 $\mathrm{m}, 41.0320^{\circ} \mathrm{N} 21.1215^{\circ} \mathrm{E}, 11.05 .2012,7$ males, 1 female, leg. Kolcsár L.-P., TörÖK E., Keresztes L. (DCBBU). Greece, Drama, Rodopi Mts., Skaloti, 985 $\mathrm{m}, 41.4159^{\circ} \mathrm{N} 24.2851^{\circ} \mathrm{E}, 28.07 .2007,6$ males, leg.
BÁLINT M. (DCBBU).

Remarks: This species is relatively common and widespread within the medium altitude mountainous areas of Central Europe, but was only sporadically found in the Balkans. Our data represents the first records from the Republic of Macedonia and from Greece. Based on the observations of the lead author (KOLCSÁR), the species is found by brooks and smaller rivers with sandy bands (Fig. 1C). D. landrocki is known to exhibit a bivoltine phenology in Central Europe.

Pedicia (Crunobia) straminea (MEIGEN, 1838)

Material examined: Luxembourg, Echternach, 187 $\mathrm{m}, 49.8164^{\circ} \mathrm{N} 6.4119^{\circ} \mathrm{E}, 05.09 .2005,1$ male, leg. Keresztes L. (DCBBU).

Remarks: It is a common species, which prefers pebbly stream beds (first author observation). It is the first record from Luxembourg.

\section{Family: PEDICIIDAE}

Subfamily: ULINAE

\section{Ula (Ula) mollissima (HALIDAY, 1833)}

Material examined: Republic of Macedonia, Novo Selo, Bistra Mts., Marlovo National Park, 990 m, $41.7194^{\circ} \mathrm{N} 20.8289^{\circ} \mathrm{E}, 29.06 .2017,2$ males, leg. KolCsÁr L.-P., TÖRÖK E. (DCBBU); Izvor, Treska river, $755 \mathrm{~m}, 41.4802^{\circ} \mathrm{N} 20.8347^{\circ} \mathrm{E}, 1$ male, 1 female, leg. KolCSÁr L.-P., TöRÖK E. (DCBBU).

Remarks: A common woodland species associated with fungi. This is the first record from the Republic of Macedonia.

\section{Aknowledgements}

The authors thank Dávid Murányi, Miklós Bálint and Graf Wolfram for collecting specimens. We thank Pete Boardman for his comments on the text.

\section{References}

Alexander C. P. (1975) New or little-known crane flies from Iran. I. (Diptera: Tipulidae). Journal of the New York Entomological Society 82: 279-284.

DÉnes A.-L., Kolcsár L.-P., TöröK E. and Keresztes L. (2016) Taxonomic revision of the Carpathian endemic Pedicia (Crunobia) staryi species-group (Diptera, Pediciidae) based on morphology and molecular data. ZooKeys 569: 81-104.

Gao J., Shin C., Kopeć K., Krzemiński W. and Ren D. (2015) New species and revision of Pediciidae (Diptera) from the Middle Jurassic of northeastern China and Russia. Zootaxa 3964: 77-86.

Hancock E.G., Hewitt S.M., Horsfield D., Lyszkowsi M., MacGowan I., Ricarte A., Rotheray G. and WatT K. (2015) Nematocera flies recorded in Serra do Courel, northwest Spain, May 2012 (Diptera: Anisopodidae, Blepharoceridae, Cylindrotomidae, Limoniidae, Pediciidae, Tipulidae and Trichoceridae) including descriptions of two new species of Limoniidae. Zootaxa 3911: 231-244. 


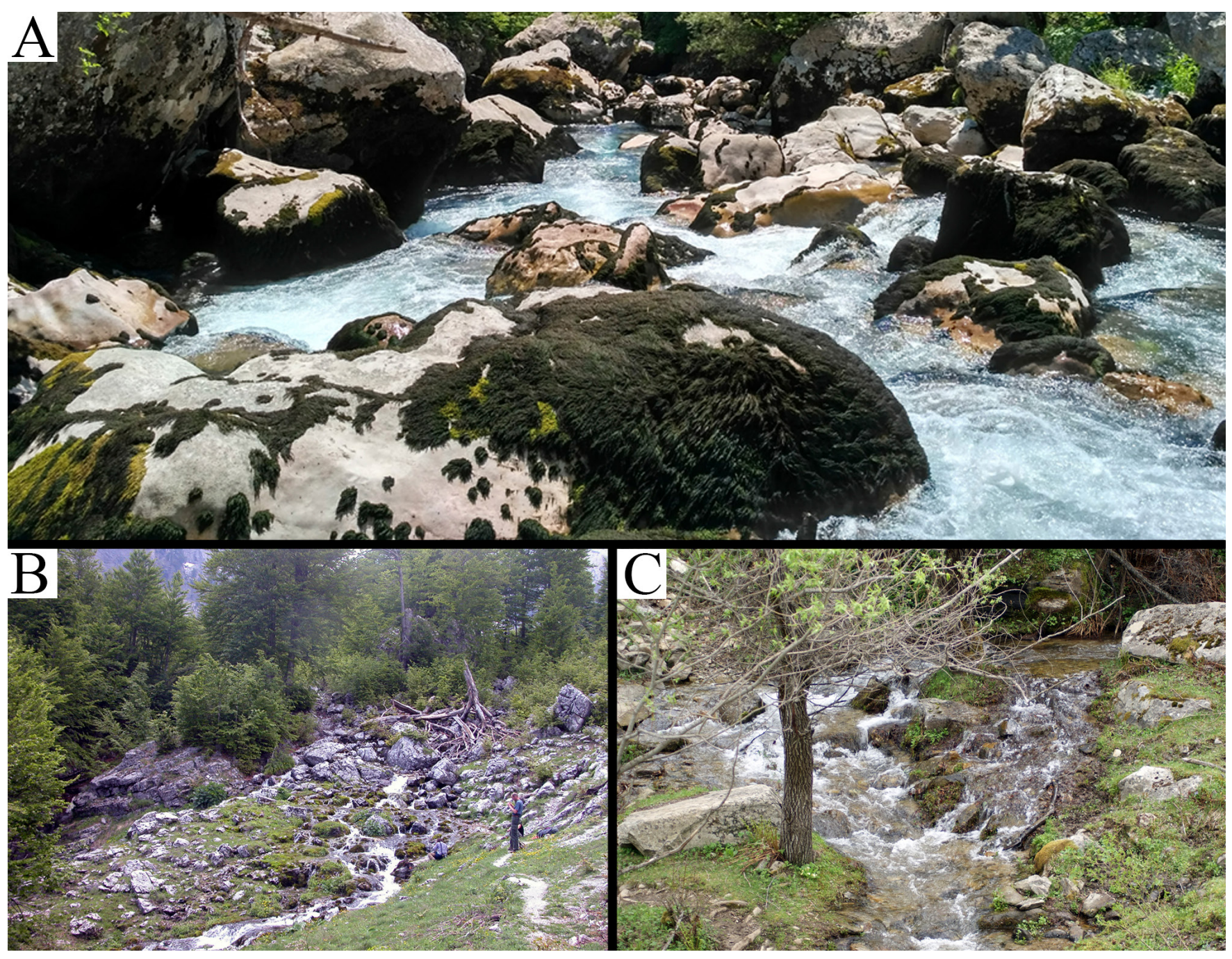

Fig. 1. Habitat photos: A - Mrtvica River, Medjurecje, Montenegro, 23.06.2017, photo: TöRÖK E.; B - spring system of the River Valbona, Rrogam, Albania, photo: MurÁnYi D.; C - Maloviste, Pelister Mts., Macedonia, 11.05.2012, photo: Kolcsár L.-P.

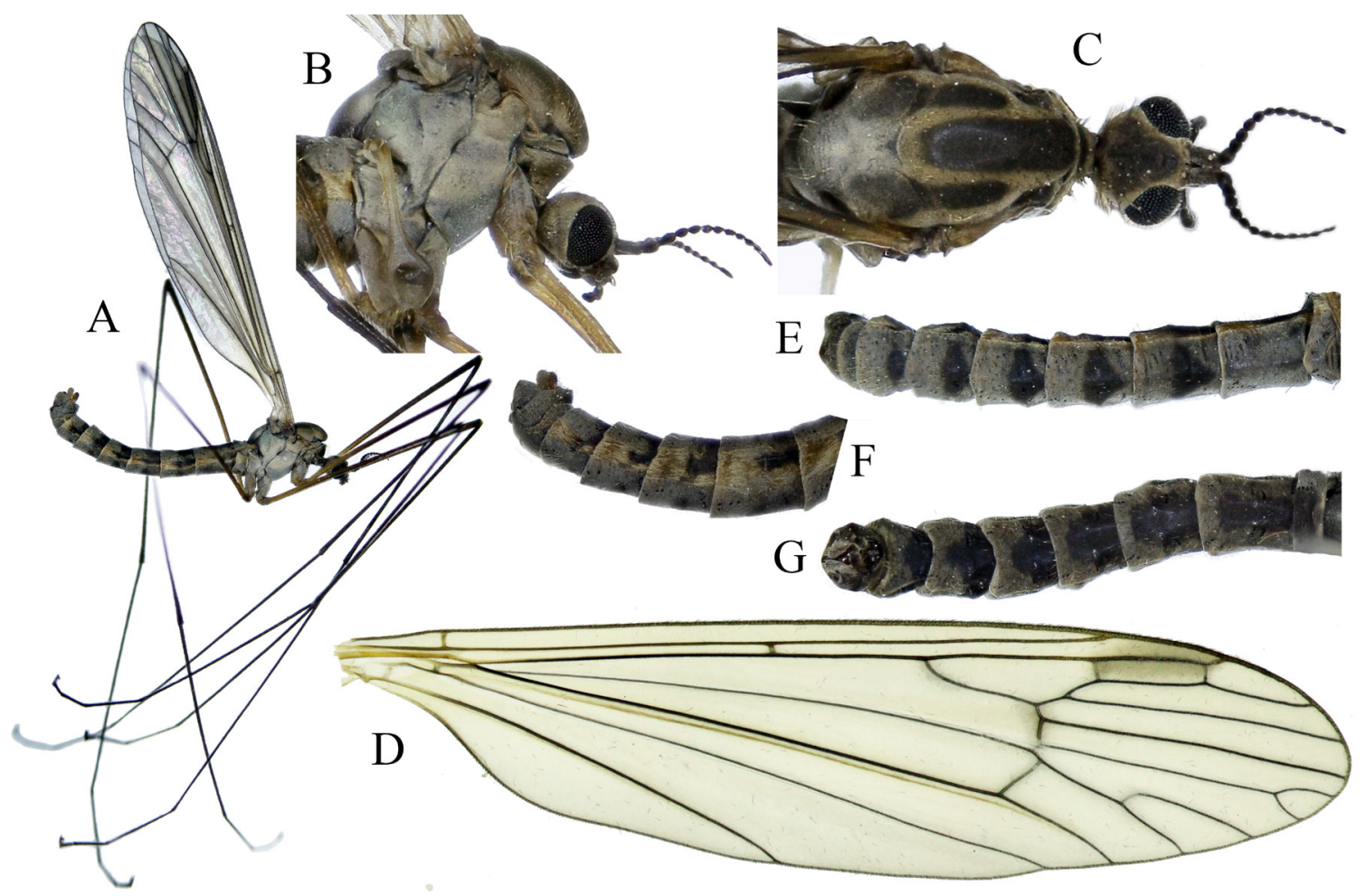

Fig. 2. Dicranota (Paradicranota) landrocki CzIzeK, 1931: A - habitus lateral view; B - thorax and head lateral view; C thorax and head dorsal view; D - right wing, E-F - abdomen: E - ventral view; F - lateral view; $\mathrm{G}$ - dorsal view. Photos were taken from a specimen collected in Gârbău Valley, Cluj-Napoca, Romania, 15.04.2017. 


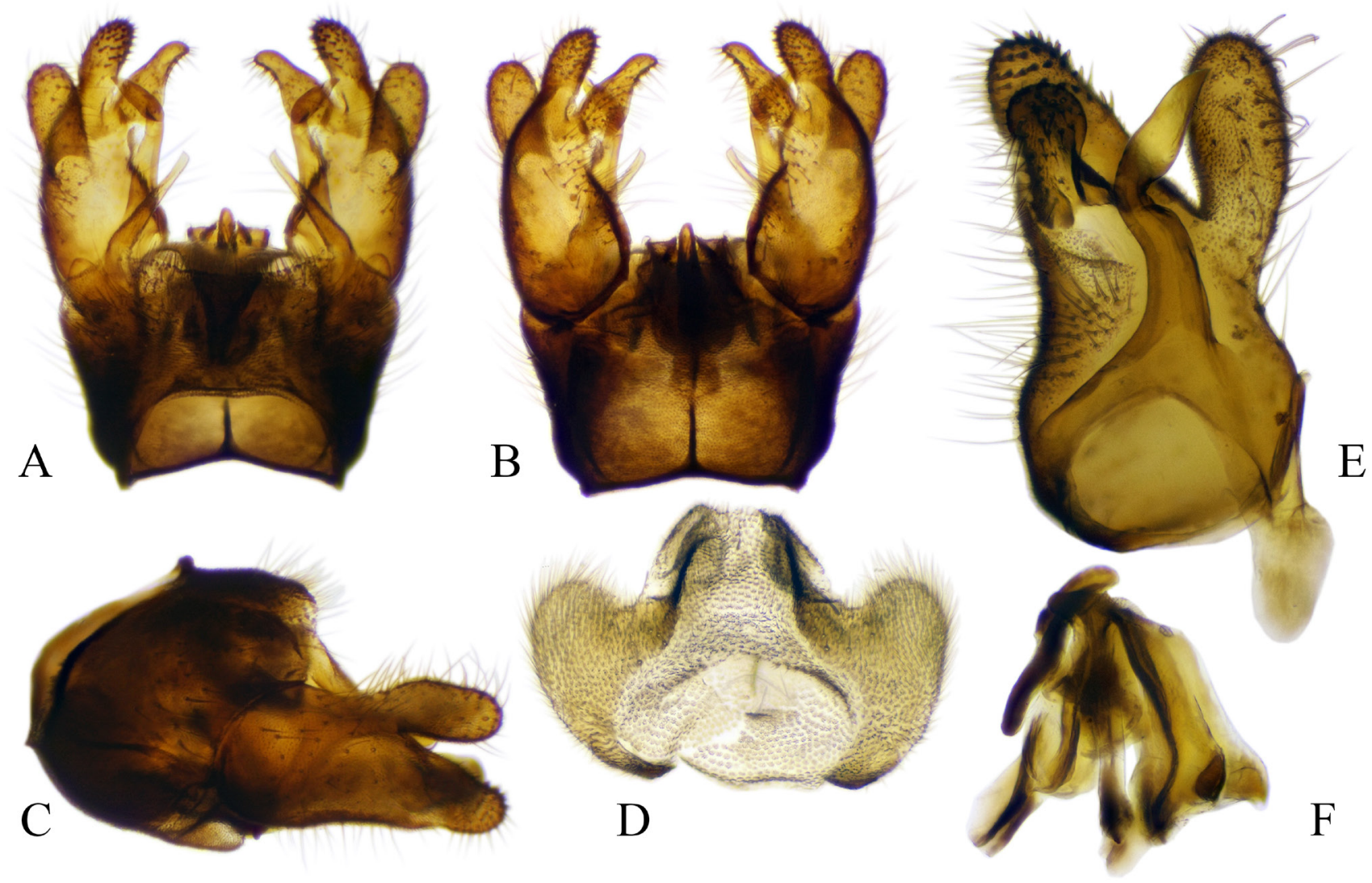

Fig. 3. Dicranota (Paradicranota) landrocki CzIzeK, 1931: A - male hypopygium dorsal view; B - male hypopygium ventral view; $\mathrm{C}$ - male hypopygium lateral view; D - proctiger dorsal view; $\mathrm{E}$ - gonocoxite inner lateral view; $\mathrm{F}$ - aedeagus complex lateral view. Photos were taken from a specimen collected in Gârbău Valley, Cluj-Napoca, Romania, 15.04.2017.

Keresztes L., Kolcsár L.-P., TöröK E. and DÉnes A.L. (2011) The spring dwelling dipteran genus Pedicia LATREILLE in the Carpathian area: diversity, divergence and distribution - case studies. In: KerESZTES, L. and MARKó B. (eds.): The Carpathians as speciation centres and barriers: from case studies to general patterns. Cluj University Press, Cluj-Napoca, Romania.

Kolcsár L.-P. and Keresztes L. (2016) New records of Pediciidae (Diptera: Tipuloidea) from Hungary. Folia Entomologica Hungarica 77: 119-126.

Kolcsár L.-P. and TöRÖK E. (2017) New faunistic records of Pediciidae (Diptera) from Ukraine. Ukrainska Entomofaunistyka 8: 25-26.

Kolcsár L.-P., TöröK E. and Keresztes L. (2012) An annotated list of Pediciidae (Insecta, Diptera) from Romania with a revision of the literature data. Entomologica romanica 17: 21-27.

Kolcsár L.-P., Dénes A.-L., TöröK E., Keresztes L. (2014) Comparing morphological diversity with genetic structuring in the case of the Dicranota (Ludicia) lucidipennis (EDWARDS, 1921) (Diptera: Pediciidae). Abstract 8th International Congress of Dipterology: 178.

Kolcsár L.-P., Ivković M. and TernjeJ I. (2015) New records of Limoniidae and Pediciidae (Diptera) from Croatia. ZooKeys 5: 23-37.

Kolcsár L.-P., Veres R. and Keresztes L. (2018) TransDiptera Online Database. http://transdiptera.ro. accessed on: 04.01.2018. https://doi. org/10.18426/ OBM.5sskmll13ip0

Lantsov V.I. (2012) New for the Central Caucasus: Dicranota parviuncinata SAV. (Diptera: Pediciidae), with data on its distribution and ecology. Caucasian Entomological Bulletin 8: 339-341.

Mederos J. and EiroA E. (2015) Nuevos datos de Limoniidae, Pediciidae y Tipulidae(Diptera: Tipuloidea) de los Pirineos Centrales (Cataluna, Espana). Boletin de la Sociedad Entomologica Aragonesa 56: 265-268.

Oosterbroek P. (2018) Catalogue of the Craneflies of the World (Diptera, Tipuloidea: Pediciidae, Limoniidae, Cylindrotomidae, Tipulidae), http://ccw.naturalis.nl/, accessed on 04.01.2018.

ÖzGüL O. and Koç H. (2016) Contributions to the Pediciidae (Diptera) fauna of Turkey with six new records. Turkish Journal of Zoology 40: 779-784.

Paramonov N.M. (2009) A new species of Pedicia s.str. (Diptera: Pediciidae) from the North Caucasus, Russia. In: LANTSOV V. (ed.): Crane flies. History, taxonomy and ecology (Diptera: Tipulidae, Limoniidae, Pediciidae, Trichoceridae, Ptychopteridae, Tanyderidae). Memorial volume dedicated to Dr. Charles Paul Alexander (1889-1981), Dr. Bernhard Mannheims (1909-1971) and Dr. Evgeniy NiKolaEvich SAVCHENKo (1909-1994). Zoosymposia 3: 199-202.

StARÝ J. (2007) Nomenclatural changes in West Palaearctic Limoniidae and Pediciidae (Diptera), II. Casopis Slezskeho Musea v Opava (A) 56: 23-36.

StARÝ J. (2014) Some records of Limoniidae and Pediciidae (Diptera) from Portugal and Spain. Acta Musei Silesiae, Scientiae Naturales 63: 83-95.

Ujvárosi L. and Starý J. (2003) A new Pedicia (Crunobia) from Romania and other four species new to the country's fauna (Diptera: Pediciidae). Entomologica Romanica 7: 45-50. 
Ujvárosi L. and BÁLINT M. (2012) Discovery of the second European Amalopis species: an integrative survey of the widespread Pedicia (Amalopis) occulta (MeIGEN, 1830) (Insecta, Diptera, Pediciidae). Zootaxa 3189: 1-28.
Levente-Péter KoLCSÁR

Hungarian Department of Biology and

Ecology, Centre of Systems Biology,

Biodiversity and Bioresources,

Babeș-Bolyai University, Clinicilor 5-7,

Cluj-Napoca, Romania

E-mail: kolcsar.peter@gmail.com

Accepted: 15.03 .2018

Published online: 31.12 .2018

Published: 31.12.2018

Online article number: ER22201801

doi: 10.24193/entomolrom.22.1
Edina TöRÖK

Hungarian Department of Biology and

Ecology, Centre of Systems Biology,

Biodiversity and Bioresources,

Babeș-Bolyai University, Clinicilor 5-7,

Cluj-Napoca, Romania

Romanian Academy Institute of Biology,

Splaiul Independenţei 296, 060031

București, Romania

E-mail: edinatorok7@gmail.com
Lujza KeRESZTES

Hungarian Department of Biology and

Ecology, Centre of Systems Biology,

Biodiversity and Bioresources,

Babeș-Bolyai University, Clinicilor 5-7,

Cluj-Napoca, Romania

E-mail: keresztes2012@gmail.com 